Guest Editorial, part of a Special Feature on The Privilege to Fish

\title{
The Privilege to Fish
}

\author{
Mimi E. Lam ${ }^{l}$ and Meaghan E. Calcari Campbell ${ }^{2}$
}

Key Words: catch shares; dedicated access privileges; fishing access rights and duties; fishing ecosystem-based management; marine conservation; overfishing; public trust; social responsibility; stewardship

\section{INTRODUCTION}

Fisheries management has failed to stop overfishing. Private individuals and enterprises that use public fishery resources are subject to legal obligations and harvest rules, though these regulations are often poorly enforced. The privilege to fish is commonly perceived as a right to fish, which has serious consequences for the sustainability of target fish species and conservation of marine resources. To mitigate the collective human impact on marine ecosystems, global society must reconcile the ecological, economic, social, cultural, political, legal, and ethical ramifications of competing human demands on scarce natural resources. This Special Feature is the product of an American Association for the Advancement of Science symposium organized by the guest editors. In the collection of papers that follow, biologists, resource managers, policy analysts, economists, lawyers, tribal leaders, and conservationists tackle pressing issues in marine resource management and governance, such as, "Who is responsible for managing and protecting fishery resources? What governance mechanisms can resolve local and global fishery resource conflicts over shared access rights? How can competitive globalized markets and the visible hand of subsidies be reined in to end the race for fish, and instead, support local communities and global society?" The diverse perspectives captured in this Special Feature reflect the complexity of these issues.

In the absence of oceanic fences, wild fish migrate: living fish obey natural laws, while human behavior must be constrained by social laws. Historically, community-based management and customary law supported Aboriginal subsistence fisheries and traditional ways of life. Today, ecosystem-based management (EBM) and science assist centralized governments in regulating industrialized, mixed-stock fisheries, using various input and output controls in management and governance (Sissenwine and Mace 2003). Input controls, such as licenses, gear restrictions, area closures, and limits on days fished, restrict access; output controls limit the fishery by setting the total allowable catch (TAC), and often include catch shares that allocate a portion of the TAC either by sector, gear type, or vessel, or alternatively, to individual fishermen, communities, or fishery associations. While each of these management schemes may have been designed to achieve unique social, economic, and ecological goals, they were often historically constructed to achieve the least socio-political resistance and ecological damage, and the greatest economic return (Bromley 2009).

To date, ethical issues concerning socioeconomic equity and ecological sustainability have seldom been captured in fishery management program design or implementation. How can these various management practices and tools contribute to the sustainable harvest of marine resources today, as an obligation to present and future fishing communities and global society? Fisheries managers must reconcile how to grant rights of access and harvest with attendant responsibilities of marine stewardship. With duties, the erstwhile rights now constitute privileges. The "privilege of utilizing a resource carries with it the obligation" to conserve wild living resources (Holt and Talbot 1978, quoted in Mangel et al. 1996, p. 339). For conservation, fisheries management needs to shift from rights-based fishing to dedicated access privileges. Dedicated access privileges combine aspects of both input and output controls by providing secure access privileges to a portion of the allowable catch, fishing effort, or fishing grounds. The articles in this Special Feature explore these complex issues of fishing to articulate the privilege to fish, where responsible management of marine resources is an ecological norm, and marine conservation, a societal value.

\section{THE ABORIGINAL RIGHT TO FISH}

For millennia, in the Pacific Northwest, pre-contact indigenous societies sustained local aquatic resources through a stewardship ethic that coupled marine resource management to responsibility via cultural norms and community sanctions (Trosper 2003). Traditional Aboriginal fisheries management and governance constituted a "sacred alliance" (D. Blaney, Homalco First Nation, personal communication), where tribal stewards of streams served as resource managers for their communities, including their sacred relatives, the salmon. Prior to contact with Europeans, exclusive rights to terminal salmon fisheries enforced through rigorous reciprocity relations among coastal tribes permitted conflict resolution, information feedback, and salmon husbandry, argues Johnsen (2009). Jones et al. (2010) describe Haida First Nation's ethics and conservation as they relate to EBM and marine spatial planning in the Pacific North Coast Integrated Management Area, a modern cogovernance partnership between the

\footnotetext{
${ }^{1}$ University of British Columbia, Fisheries Centre, Policy and Ecosystem Restoration in Fisheries, ${ }^{2}$ Gordon and Betty Moore Foundation
} 
Canadian and British Columbian governments and the coastal First Nations, whose rights to fish are constitutionally protected.

\section{THE PRIVATE PRIVILEGE TO FISH}

The private privilege to fish has often been erroneously perceived and managed as a right, by not tethering access privileges with fiduciary responsibilities for the sustainable management of fisheries and conservation of living marine resources. Lam and Pauly (2010) argue that the implicit social contract among governments, private fishing enterprises, and the public must be renegotiated to sustain ethical fisheries that not only conserve fish stocks, but also fishing livelihoods, communities, and ways of life. To promote conservation in fisheries management and policy, Rosenberg (2009) prescribes EBM, management integrated across all sectors of human activity, including coastal and marine spatial planning, and an incentive structure promoting stability of fisheries. Sumaila (2010) highlights some strengths and weaknesses of individual transferable quotas (ITQs), one type of catch share, and offers suggestions on how to design and implement ITQs to achieve ecological, economic, and social sustainability of fisheries within an EBM approach. Eagle and Kuker (2010) first critique public fisheries by dissecting the challenges of the decision-making processes in government ownership and regulation of natural resources, then offer prescriptions for achieving more efficient and equitable outcomes, such as zoning fishing interests by sector or area, which could enhance results and accountability.

\section{THE PUBLIC TRUST IN FISHERIES}

With increasing fisheries collapses and declining stocks, the human dimensions of fisheries, particularly the ethical dimension, must be critically analyzed within the context of the public trust in fisheries (Turnipseed et al. 2009). Pitcher and Lam (2010) argue that only with well-defined policy goals and composite management strategies, such as EBM and historically based ecosystem restoration, can the analyses of quantitative stock assessments, establishment of marine protected areas, comanagement arrangements, and other "fisheries management solutions" be effective in protecting the public's right to fish for food security. To sustain global fisheries, Lam (2012) argues for incorporating a harm principle in fisheries that is both instrumental and ethical, namely: (1) regulate the fishing industry with management tools that internalize the social and environmental costs of fishing, by requiring fishermen to pay for the privilege to fish via access and extraction fees, both scaled with fishing capacity; (2) develop fisheries policies with the explicit goal to reduce fishing harm so as to help achieve sustainable fisheries and marine conservation; (3) legislate binding laws to create and regulate societal norms that protect the public trust in fisheries; and (4) adopt a collaborative fisheries governance framework that shares the decision-making rights and responsibilities of marine stewardship among government, the fishing industry, and civil society.

\section{CONCLUDING REMARKS}

In 1883, in response to concerns about overfishing, Thomas H. Huxley infamously declared at the International Fisheries Exhibition in London, UK that "...with existing methods of fishing, it is inconceivable that the great sea fisheries ...could ever be exhausted" (Sims and Southward 2006, Roberts 2007): today, they are indisputably being exhausted (Pauly 2007). While the papers collected in this Special Feature do not offer a unique management strategy or policy tool to tackle modern societal and ecological challenges associated with fisheries, they do spotlight the privilege to fish and synthesize diverse cultural and disciplinary perspectives. Collectively, they promote an integrated ecosystem approach to protect living marine resources and the communities dependent upon them. Only by continuing to adapt fisheries management and policies in response to emerging ecological and human developments, such as tethering social responsibilities with individual rights, can ethical fisheries evolve, with fishing rights redefined as privileges.

Responses to this article can be read online at: http://www.ecologyandsociety.org/issues/responses. php/4156

\section{LITERATURE CITED}

Bromley, D. W. 2009. Abdicating responsibility: the deceits of fisheries policy. Fisheries 34(6): 280-290. http://dx.doi. org/10.1577/1548-8446-34.6.280

Eagle, J., and A. Kuker. 2010. Public fisheries. Ecology and Society 15(1): 10. [online] URL: http://www.ecologyandsociety. org/vol15/iss1/art10/.

Johnsen, D. B. 2009. Salmon, science, and reciprocity on the Northwest Coast. Ecology and Society 14(2): 43. [online] URL: http://www.ecologyandsociety.org/vol14/iss2/art43/.

Jones, R., C. Rigg, and L. Lee. 2010. Haida marine planning: First Nations as a partner in marine conservation. Ecology and Society 15(1): 12. [online] URL: http://www.ecologyandsociety. org/vol15/iss1/art12/.

Lam, M. E. 2012. Of fish and fishermen: shifting societal baselines to reduce environmental harm in fisheries. Ecology and Society 17(4): 18. http://dx.doi.org/10.5751/ES-05113-170418

Lam, M. E., and D. Pauly. 2010. Who is right to fish? Evolving a social contract for ethical fisheries. Ecology and Society 15 (3): 16. [online] URL: http://www.ecologyandsociety.org/ vol15/iss $3 /$ art16/. 
Mangel, M., L. M. Talbot, G. K. Meffe, M. T. Agardy, D. L. Alverson, J. Barlow, D. B. Botkin, G. Budowski, T. Clark, J. Cooke, R. H. Crozier, P. K. Dayton, D. L. Elder, C. W. Fowler, S. Funtowicz, J. Giske, D. Ludwig, K. Magnusson, B. S. Malayang III, C. Mann, E. A. Norse, S. P. Northridge, W. F. Perrin, C. Perrings, R. M. Peterman, G. B. Rabb, H. A. Regier, J. E. Reynolds III, K. Sherman, M. P. Sissenwine, T. D. Smith, A. Starfield, R. J. Taylor, M. F. Tillman, C. Toft, J. R. Twiss, Jr., J. Wilen, and T. P. Young. 1996. Principles for the conservation of wild living resources. Ecological Applications 6(2): 338-362. [online] URL: http://www.jstor.org/ stable/2269369

Pauly, D. 2007. The Sea around Us Project: documenting and communicating global fisheries impacts on marine ecosystems. Ambio 36(4): 290-295.

Pitcher, T. J., and M. E. Lam. 2010. Fishful thinking: rhetoric, reality, and the sea before us. Ecology and Society 15(2): 12. [online] URL: http://www.ecologyandsociety.org/vol15/iss2/ art12/.

Roberts, C. M. 2007. The unnatural history of the sea. Island Press, Washington, D.C., USA.

Rosenberg, A. A. 2009. Changing U.S. ocean policy can set a new direction for marine resource management. Ecology and Society 14(2): 6. [online] URL: http://www.ecologyandsociety. org/vol14/iss2/art6/.

Sims, D. W., and A. J. Southward. 2006. Dwindling fish numbers already of concern in 1883. Nature 439: 660. http:// dx.doi.org/10.1038/439660c

Sissenwine, M. P., and P. M. Mace. 2003. Governance for responsible fisheries: an ecosystem approach. Pages 363-391 in M. Sinclair and G. Valdimarsson, editors. Responsible fisheries in the marine ecosystem. Food and Agriculture Organization of the United Nations, Rome, Italy.

Sumaila, U. R. 2010. A cautionary note on individual transferable quotas. Ecology and Society 15(3):36. [online] URL: http://www.ecologyandsociety.org/vol15/iss3/art36/.

Trosper, R. L. 2003. Resilience in pre-contact Pacific Northwest social ecological systems. Conservation Ecology 7(3):6. [online] URL: http://www.ecologyandsociety.org/ vol7/iss $3 /$ art6/.

Turnipseed. M., L. B. Crowder, R. D. Sagarin, and S. E. Roady. 2009. Legal bedrock for rebuilding America's ocean ecosystems. Science 324:183-184. http://dx.doi.org/10.1126/ science. 1170889 